\title{
О.О. Шкиль
}

Омский государственный университет

\section{Лексема «бесцельный» в пространстве телеологической оценки}

Аннотация: В статье представлены результаты когнитивно-семантического анализа лексемы «бесцельный». Автор рассматривает значение данного предиката в рамках проблемы выражения телеологической оценки в русском языке. Выявлены значения лексемы, не зафиксированные в толковых словарях современного русского языка.

There are the results of the kognitive-semantic analysis of the lexeme «aimless» are presented in the article. The author considers the meaning of the predicate in the network of the problem of the teleological estimation expression in Russian language. There are meanings of the lexeme which have not been fixed in explanatory dictionaries of the modern Russian are revealed.

Ключевые слова: целевые отношения, телеологическая оценка, высказывание, контекст, пресуппозиция.

Target relations, teleological estimation, expression, context, presuppozitsiya.

УДК: 801.

Контактная информация: Омск, пр. Мира 55-а. ОмГУ, филологический факультет. Тел. (3812) 423473. E-mail: olgashkil@gmail.com.

Целевым отношениям были посвящены исследования таких отечественных лингвистов, как В.А. Белошапкова, Т.В. Булыгина, В.Б. Евтюхин и др. В их работах выделяются следующие основные признаки целевых отношений: сознательное динамическое действие [Белошапкова, 1970, с. 725], контролируемость ситуации [Булыгина, 1982, с. 70-71]. В.Б. Евтюхин говорит о «двуедином» (имея в виду активную деятельность / физическую активность и контролируемость / сознательность) признаке цели - активности (субъектной активности) [ТФГ, 1996, с. 164]. Иными словами, целевые отношения маркируются в языке как осознанные и контролируемые.

Кроме того, как замечает М.В. Ляпон, целевые отношения предполагают соотнесение двух ситуаций, одна из которых сообщает о предпосылке, предопределяющей, обеспечивающей ожидаемое следствие, а другая объединяет значение стимула и потенциального или реального результата; для целевых предложений характерно значение целенаправленности [Русская грамматика, 1982, с. 594]. Наиболее ярким примером выражения целевых отношений является сложноподчиненная конструкция: Я задержался (предпосылка), чтобы поговорить с коллегой (стимул, потенциальный результат).

Целевые отношения (которые предполагают направленность субъекта на цель) лежат в основе телеологической оценки (далее - Т-оценка), которая до сих пор не становилась предметом специальных исследований.

Предлагаем разграничить широкое и узкое понимание Т-оценки. В широком смысле Т-оценка - частная оценка, которая квалифицирует деятельность человека (а также группы, общества) с позиций направленности на определенную цель (це- 
ленаправленный), достижения / недостижения определенной цели (эффективный, неэфффективный, результативный, безрезультатный), перспектив (прогнозов) относительно достижения / недостижения цели (целесообразный, нецелесообразный). С нашей точки зрения, направленность на цель следует рассматривать как пресуппозицию, логическую предпосылку высказываний, содержащих собственно Т-оценку. Следовательно, в узком смысле Т-оценка характеризует деятельность человека с позиций достижения / недостижения определенной цели и перспектив (прогнозов) относительно достижения / недостижения цели.

Таким образом, Т-оценка имеет отношение к понятиям «цель», «целеполагание», «целенаправленность», «целесообразность».

Цель - «идеальный или реальный предмет сознательного или бессознательного стремления субъекта; финальный результат, на который преднамеренно направлен процесс» [Новая философская энциклопедия, 2001, с. 317], «мысленно предвосхищаемый результат деятельности» [Большой Российский энциклопедический словарь, 2007, с. 1739]. Отметим, что утверждение о том, что цель является результатом бессознательной деятельности человека, не является общепринятым. В приведенных выше определениях отражается позиция автора статьи: цель может быть неосознаваемой.

Целесообразность трактуется как «соответствие явления или процесса определенному (относительно завершенному) состоянию, материальная или идеальная модель которого представляется в качестве цели» [Новая философская энциклопедия, 2001, с. 314]. Мы будем определять целесообразность как соответствие результатов деятельности прогнозам относительно достижения / недостижения цели.

Понятие целесообразности связывается философами с целеполаганием как «существенным элементом человеческой деятельности, характеризующим как мыслительные процессы, так и предметную деятельность человека, прежде всего процесс труда» [Там же, 2001, с. 315]. В рамках аксиологического подхода будем дефинировать целеполагание как ментальное состояние деятеля, заключающееся в направленности на определенный результат.

Целенаправленность - «характеристика деятельности, направленной на достижение определенного конечного результата (цели) < ..> Целенаправленность характеризует поведение любых сложноорганизованных систем - будь то деятельность человека, живого организма или технического устройства, снабженных механизмами своего поведения по принципу обратных связей» [Философский словарь, 2001, с. 644-646].

Очевидно, что целеполагание - это ментальный процесс, присущий только человеку, в то время как целенаправленность может характеризовать не только действия человека, но и действия животных и даже некоторых механизмов. Следовательно, понятие «целенаправленность» шире понятия «целеполагание».

Т-оценки присваиваются практической деятельности человека с опорой на разумное, рациональное начало личности, то есть субъект Т-оценки - человек рациональный, анализирующий. Объектом Т-оценки является человек практический, деятельный, действующий. Основанием Т-оценки служит анализ ситуации, практика, опыт, определенные данные или чистое умозаключение.

Целью данной статьи является исследование семантики лексемы бесиельный (бесцельно) в рамках вопроса о Т-оценке. Материалом для наблюдений послужили примеры из Интернет-ресурса - Национального корпуса русского языка [НКРЯ].

В «Словаре русского языка» С.И. Ожегова [2007, с. 58] слово бесиельный толкуется как «не имеющий определенной цели, бесполезный». Обращение к функционированию данной единицы позволяет предположить, что в зависимости от контекста предикат бесиельный (бесиельно) выражает и другие, иногда неожиданные значения. Здесь рассмотрим три таких значения. 


\section{I. Значение «безрезультатный»}

Предикат бесцельный (бесцельно) может указывать на отрицательный результат попыток человека достичь какой-либо цели. В этом случае основанием оценки является рациональный анализ ситуации (как правило, связанный с прошлым опытом), который «подсказывает» субъекту оценки, что положительный результат действий не достигнут, не может быть достигнут или не будет достигнут по каким-либо причинам. Приведем примеры: (1) To, что вы мне писали о соединении Ефремова с МХАТом, я считаю абсолютно ненужным, бесиельным (Семен Данилюк. Рублевая зона); (2) Сегодня мне по-настоящему горько и стыдно за бесиельно потраченные на предвыборную кампанию народные и немного свои деньги (Дело, 2002. 08. 31); (3) Иногда он любит повторять слова книжного героя покойного Виля Липатова: "Спор - это бесиельное убийство времени: истину рождает эксперимент» (Наш современник, 2002); (4) Путин не поехал на саммит НАТО, потому что не любит посещать некомпетентные и бесцельные мероприятия (Пресс-конференция Павловского и А. Кокошина, Москва // 2004.07. 01); (5) Такие больные утверждают, что лечение бесиельно, но указания врачей выполняют пунктуально (100\% здоровья, 2003).

В приведенных высказываниях актуальна позиция наблюдателя-аналитика и неявно присутствует информация о том, что определенные человеческие действия (в примерах они выделены подчеркиванием) производятся с какой-либо целью, а значит, есть направленность на результат, или пресуппозиция Т-оценки. В данном случае предикат бесцельный (бесцельно) синонимичен лексеме безрезультатный (безрезультатно) и указывает на отсутствие положительного результата деятельности, то есть выражает собственно Т-оценку (Т-оценку в узком смысле) с точки зрения достижения / недостижения цели.

\section{II. Значение «не осознавая цели»}

Как было отмечено ранее, целевые отношения связаны с активной / физической и сознательной / контролируемой деятельностью человека, выражаются бинарной структурой «предпосылка - стимул (ожидаемый результат)» и имеют значение целенаправленности. Иными словами, активная физическая деятельность, как правило, имеет сознательную цель, то есть деятель осознает взаимообусловленность предпосылки осуществления цели и стимула (потенциального результата действия). Однако в некоторых случаях, как показывают контексты, человек не осознает цели своих действий, и тогда предпосылка реализации цели может сопровождаться определителем бесиельный (бесиельно). Соответствующие высказывания отражают неосознанную, но целенаправленную человеческую деятельность. Информация о цели действий в таких высказываниях передается косвенно. Она не формулируется, поскольку связана с внутренним (психологическим) состоянием человека. В этом случае предпосылкой (которая, как правило, эксплицируется) осуществления цели является физическое движение, а стимулом (в типичном случае имплицированным) - изменение психологического состояния в лучшую сторону. Приведем примеры: (6) Дома она не могла найти места бесиельно бродила по саду, мяла в руках сорванный листик, пыталась убедить себя, что на самом деле ничего особенного не произошло (Татьяна Тронина. Русалка для интимных встреч); (7) После этого разговора Голев выкурил подряд две сигареты и пошел бесчельно вверх по улице (Звезда, 2002); (8) Она встала и, сжимая руки, бесиельно прошлась по комнате (Татьяна Тронина. Никогда не говори «навсегда» (2004); (9) Ваня бесцельно потыкался из угла в угол и сел, не утииив угрызений совести (Александр Фадеев. Молодая гвардия).

В приведенных высказываниях передается информация о том, что деятель испытывает душевный дискомфорт и, чтобы успокоиться, совершает определен- 
ные физические действия. См. выражение семантики тревожного душевного состояния деятеля в контекстах предиката: (6) не могла найти места, мяла в руках сорванный листик; (7) выкурил подряд две сигареть; (8) сжимая руки; (9) не утишив угрызений совести. Предпосылка достижения неосознанной цели («успокоиться») в этих высказываниях эксплицирована: (6) бесцельно бродила; (7) пошел бесцельно; (8) встала и бесцельно прошлась; (9) бесцельно потыкался из угла в угол и сел. А стимул - «чтобы успокоиться» - имплицирован. На него косвенно указывает лексика ближайшего контекста, отражающая душевное беспокойство.

Как показывают вышеперечисленные примеры $(6,7,8,9)$, с позиций деятеля «бесцельные» действия оправданны и «небесцельны», поскольку являются реакцией на стресс, душевный дискомфорт (связанный с состоянием тревоги, волнения, беспокойства и т. п.). Поступки, движения человека в таких случаях связаны с подсознательной целью - обрести «точку опоры», душевное равновесие.

Таким образом, предикат бесцельный (бесцельно) характеризует неосознанные, но целенаправленные человеческие действия, то есть имеет значение «не осознавая цели». Данный предикат здесь не выражает T-оценку, так как есть направленность на результат (пресуппозиция Т-оценки), но нет сознательного стремления человека к цели, нет и позиции аналитика - субъекта Т-оценки. Собственно же Т-оценка в данных высказываниях может присутствовать за пределами лексемы бесиельный, если есть информация о том, достигнут определенный результат или не достигнут. Так, в примере (9) фраза «не утишив угрызений совести» репрезентирует собственно Т-оценку с точки зрения достижения / недостижения результата: свидетельствует об отрицательном результате попыток достичь цели - успокоить совесть.

\section{III. Значение «без определенной цели»}

Предикат бесцельный (бесцельно) в контексте может характеризовать перемещение человека в пространстве, не преследующее определенной цели, и в этом случае лексема бесиельный употребляется в своем словарном значении «без определенной цели» и не репрезентирует T-оценку. Такое перемещение передается сочетанием определителя бесцельный (бесцельно) с глаголами направленного (кататься, идти, ехать, двигаться, продвигаться) и ненаправленного (бродить, блуждать, шататься, болтаться) движения. Приведем примеры: (10) Бродили бесиельно, дремали возле труб (Сергей Юрский. Бумажник Хофманна); (11) Когда-то сильные, красивые люди, они теперь бесиельно бродят, точно призраки, среди шалашей из мешковины и ящиков (Д.А. Гранин. Месяц вверх ногами); (12) Мы бесиельно бродили по городу, и почему-то я все время вспоминал ключника, здесь побывавшего (Валентин Катаев. Алмазный мой венец); (13) Я уже два дня бесиельно езжу по городу (Юность, № 6, 7; 1961); (14) Навстречу так же лениво и бесцельно шел человек в кирзовых сапогах (Татьяна Набатникова. День рождения кошки).

Возможно, движение без цели, актуализированное в высказываниях предикатом бесцельный (бесцельно), в некоторой степени концептуализирует недостаточную способность русского человека контролировать жизненные события; недостаточную «выделенность индивида как автономного агента, как лица, стремящегося к своей цели и пытающегося ее достичь, как контролера событий» [Вежбицкая, 1996, с. 34].

Общеоценочные смыслы некоторых глаголов движения замечены в литературе. Так, анализируя этический словник русского языка, Н.В. Орлова сделала вывод о том, что общество отрицательно относится к движению без цели, которое, в частности, передается глаголами шататься, болтаться [Орлова, 2005, c. 153]. И это не случайно, поскольку жизнь ассоциируется в русском сознании с движением, дорогой, и если не одобряется жизнь без цели, то, следовательно, 
порицается движение без цели, и наоборот. «Правильный путь обязательно имеет цель; тот, кто по нему идет, найдет свое место в жизни...» [Орлова, 2005, с. 153]. Философ Н.Ф. Федоров отмечает, что русским людям свойственно движение к определенной цели, а не простое протекание жизни в соответствии с заданными ею же условиями [Федоров, 1982]. В связи с этим не случайно, на наш взгляд, выражение субъектами речи досады, разочарования, обиды за бесиельно прожитую жизнь, бесцельное существование, бытие, бесцельную растрату (трату) энергии, потраченное время, бесчельно потерянные годы, бесчельные мероприятия и др. Приведем примеры: (15) А главное, жаль Печорина, которому не удалось погибнуть и снова надлежит жить, предсточт и дальше влачить свое бесцельное существование (Константин Рудницкий. Игра портретами); (16) ... Или найдется слишком поздно, когда лучшие годы будут уже позади, причем будут прожиты бесцельно и бездарно (Форум forum.rsuh.ru, 2005), (17) Жизнь дается один раз, и прожить ее нужно так, чтобы не было мучительно больно за бесцельно прожитые годы (Жизнь национальностей, 2004); (18) Надо точно знать, как именно ты используешь доставленное, чтобы было тебе счастье и потом не пришлось жалеть бесиельно прожитое (Автопилот, 2002. 04. 15); (19) Мне часто бывает стылно за бесиельно прожитые годы, потраченные на выживание (Виктор Левашов. Заговор патриота).

Сделаем выводы. Предикат бесцельный (бесиельно) в зависимости от контекста репрезентирует три основных значения. Во-первых, лексема бесиельный (бесцельно) может иметь значение «безрезультатный (безрезультатно)», указывать на отрицательный результат попыток человека достичь цели и выражать собственно Т-оценку с точки зрения достижения / недостижения цели. Во-вторых, она функционирует в значении «не осознавая цели», то есть характеризует бессознательные (но целенаправленные) человеческие действия, и не является репрезентантом Т-оценки в узком смысле. И, в-третьих, употребляется в значении «без определенной цели» и также не выражает собственно Т-оценку.

\section{Литература}

Белошапкова В.А. Предложения со значением цели // Грамматика современного русского литературного языка. М., 1970.

Большой Российский энциклопедический словарь. М., 2007.

Булыгина Т.В. К построению типологии предикатов в русском языке // Ceмантические типы предикатов. М., 1982.

Вежбицкая А. Язык. Культура. Познание. М., 1996.

НКРЯ - Национальный корпус русского языка. [Электронный ресурс]. Режим доступа по: www.ruscorpora.ru.

Новая философская энциклопедия: В 4 т. М., 2001. Т. 4.

Ожегов С.И. Словарь русского языка / Под общ. ред. проф. Л.И. Скворцова. 24-е изд., испр. М., 2007.

Орлова Н.В. Наивная этика: лингвистические модели. Омск, 2005.

Русская грамматика: В 2 т. М., 1982. Т. 2. Синтаксис.

ТФГ - Теория функциональной грамматики. Локативность. Бытийность. Поссесивность. Обусловленность. СПб, 1996.

Федоров Н.Ф. Сочинения. М., 1982.

Философский словарь / Под ред. И.Т. Фролова. 7-е изд., перераб. и доп. M., 2001. 